\title{
A borderless police world
}

\section{Guillermina Seri ${ }^{1}$}

Published online: 24 July 2020

(C) Springer Nature Limited 2020

Following their 2016 visit to the USA, the U.N. Working Group of Experts on People of African Descent expressed concern regarding the "alarming levels" of police brutality targeting African Americans. ${ }^{1}$ Made visible by Black Lives Matter since 2013, the killings of Michael Brown, Eric Garner, Tamir Rice and a number of other victims mobilized communities and gained national media coverage. Still, killings continued, as did unjustified detentions, police harassment and violence, taking thousands of lives and impacting "all levels of the lives of African Americans" with almost total impunity, the Working Group concluded. ${ }^{2}$

Steadily surpassing 1,000 killings by police every year, in 2020 the situation remains unchanged. ${ }^{3}$ Racist policing contributes to the over criminalization leading to world record imprisonment levels, with 2.3 million people in 7 thousand carceral institutions, a number of them for profit, and almost as twice as many people caught in the criminal system. ${ }^{4}$ Pervasive police presence across schools and as first respondents dealing with mental illness or the homelessness expands criminalization among the most vulnerable, just as police abuses are accompanied with almost total police immunity. ${ }^{5}$

While recent research, especially Keenanga Yamahtta Taylor's, ${ }^{6}$ offers a detailed reconstruction of the history of police abuses of African Americans, understanding what makes abusive policing so resilient, so scandal-immune in the US may bring us back in time, beyond national boundaries, in Badges without Borders Stuart Schrader contends. In the US, policing is not merely a domestic matter, not at least

\footnotetext{
${ }^{1}$ Report of the Working Group of Experts on People of African Descent-visit to USA of America, 19-29 January 2016 (A/HRC/33/61/Add.2), p. 7.

2 Ibidem.

3 Police Shootings Database, The Washington Post,www.washingtonpost.com/graphics/2019/national/ police-shootings-2019/; Most of the victims are male, and half of those whose race is known are African American or Latino.

4 Prison Policy Initiative, www.prisonpolicy.org/reports/pie2019.html.

5 Vitale, Alex, The end of policing (Verso, 2017).

6 Taylor, Keeanga-Yamahtta, From \#BlackLivesMatter to Black Liberation (Haymarket, 2016).
}

Guillermina Seri serig@union.edu

1 Department of Political Science, Union College, Schenectady, NY 12308, USA 
since the aftermath of WWII, when it started deploying "beat cops to police the globe." 7 The book exposes policing at the heart of a governing apparatus seamlessly extending from our local communities to the farthest posts of the US empire, relying on the continuum between policing and war.

The story goes back to the early years of the Cold War, with the need to enhance the US image in its dispute of global hegemony with the "communist" world while crushing rebel groups and keeping African Americans' demands for rights muffled. At the time, with the evils of racism exposed by the enemy Axis powers, the US self-portrayal as the leader of an expanding liberal democratic bloc required erasing evidence of its own state racism, as especially displayed by those patrolling the streets. Not that the US government was serious about eliminating racism; Racial hierarchies had to be preserved. ${ }^{8}$ As a nomenclature of capitalist social ordering defining of the US experience, race helps reinforce and stabilize capitalist exploitation as "distinct and durable social forms," Schrader explains. And to the extent that race contributes to perpetuate the dominance of capital, it has been-and remainscentral to the project of security.

Neutralizing leftists, criminals, and the recalcitrant was central to the US hegemonic efforts. Both at home and abroad, a number of those subjects happened to be coded as non-white. And the Cold War's way to stop them and all forms of popular rebellion took the form traditionally suited to deal with racialized subjects: police action supported on national security states. ${ }^{10}$ The latter included a "war to re-racialize the globe" 11 to tame the critical voices of African-American leaders demanding civil and political rights no less than those of rebellious groups abroad. US racial nomenclature and its technologies of control were exported and adapted to the most remote confines on Earth. Domestically, the shift helped recreate modalities of "racism without racists" that allowed for the preservation of the statu quo and gained legitimacy for a now portrayed as "race blind" police. On the external front, the same model was diffused through police assistance programs.

Thus, the domestic police-prison industrial complex expanded alongside the country's foreign policy, through direct interventions overseas and the training of foreign police, military, and other groups by US advisors. Since its early moves, Schrader shows, imperial US hegemony took shape as a global police project ${ }^{12}$ supported on a vision drawing on its racial identities.

Revisiting the rise of US imperial power as a police operation, Badges without Borders documents "the intertwinement of the military industrial complex and the prison-industrial complex"13 while presenting the reader with the saga of the architects of post-WWII US "global police." ${ }^{14}$ Its global character can only intensify

\footnotetext{
7 Schrader, Stuart. Badges Without Borders : How Global Counterinsurgency Transformed American Policing (University of California Press, 2019), p. 13.

8 Schrader, Badges Without Borders, p. 266.

9 Schrader, op. cit., p. 41.

10 Schrader, op. cit., p. 10.

11 Schrader, op. cit., p. 41.

12 Schrader, op. cit., p. 2.

13 Schrader, op. cit., p. 3.

14 Schrader, op. cit., p. 47.
} 
police's discretionary nature, its merely contingent relation to the law, with "no ascertainable limits. Everything that tends to promote the public welfare is a matter for the police," 15 as a Bolivian official quoted in the book puts it.

Schrader's book stands as a bold intervention bringing together critical insights on the police and the police power with a detailed, rigorous historical study supported on a groundbreaking archive. Page after page, chains of events, technologies, networks, strategic discourses (e.g., police professionalization), and biographical accounts enter the scene in Schrader's reconstruction of the US imperial police apparatus scrutinized in light of an impressive archive. Defying the traditional organization of archives alongside a domestic and international divide, Schrader assembles a variety of records, from formal and informal government reports to personal testimonies ${ }^{16}$ that bring to light the transnational contours of the most encompassing security apparatus assembled to date.

The significance of Badges without Borders cannot be overstated. Police and security networks define challenging subjects of study, run by experts in secrecy, embedded in institutional lying as in erasing their own traces and confusing those trying to understand them. It is often thanks to the narcissistic boasting or inoperancy of random officials that researchers, activists, and journalists get an inside glimpse on the police universe. Whereas previous research has exposed distinct instances of US collaboration with-repressive policing overseas, Schrader's book presents us with a view of the entire imperial edifice behind these cases. "The structuring principle of US empire has been its dependence on local proxies to manage the challenges of rule," 17 locally relying on police operations, he notes. Badges without Borders reconstructs the canvas in which those proxies and their policing developed.

At times, passages and sections read like a spy novel, with characters like Byron Engle and other twentieth century police visionaries. It was their inspiration, the author shows, that shaped US imperial expansion alongside a police rationale. Tellingly, the artifices of the US imperial police were the same ones who advanced the "carceral state" at home. ${ }^{18}$ As a result, by the 1960s, "a single repertoire" of policing was available for use both in the US and abroad. ${ }^{19}$

\footnotetext{
15 Schrader, p. 15.

16 Schrader, op. cit., p. 15.

17 Schrader, op. cit., p. 49.

18 Schrader, op. cit., p. 2.

19 Schrader, op. cit., p. 6.
} 


\section{A global police network}

If the fabrication and reproduction of a capitalist social order defines the police's reason of being, the US imperial police project brought the challenges to an unprecedented global scale. ${ }^{20}$ The demand was for systems that were flexible, attentive to detail and local idiosyncrasies in the direct governance of individuals and groups as expedite in transferring information thousands of miles away. Just as re-racializing labeling and forms of control spread globally, counterinsurgency and pacification methods first developed in (neo)colonial settings were implemented in the streets in the US. ${ }^{21}$ The institutional architecture of the enterprise was massive, monumental. And so is Schrader's book. Relentlessly, chapter after chapter, the author maps the US imperial police's post-WWII expansion. He delves into the trajectories of visionaries like Byron Engle as into the seamless domestic-foreign police crosspollination. He surveys programs based on seemingly benign forms of assistance and community support and well as (often linked) counterinsurgency operations. He describes new policing techniques for the routine identification of populations that later reappeared in the streets of major US cities in the form of "broken windows" or "stop-and-frisk." He refers tactics of riot control—including tear gas and banned chemicals, the creation of "capital intensive" ${ }^{22}$ police formations such as SWAT, and their further development traveling back and forth between US domestic scenarios and assistance programs overseas. These examples, and the expansive imperial police repertoire examined in the book uncover a "first line of defense against subversion" 23 of a global scope.

As US police leaders became "insistently transnational" 24 in their expertise and perspectives, a synergy enhanced the exchange of institutions, principles, techniques, and practices domestically and abroad. ${ }^{25}$ "Not just repatriated," the lessons learned in subjugating rebellious locals abroad became part of the US policing repertoire from the start, Schrader notes. ${ }^{26}$ Central to these efforts was the call for police professionalization. As it was the attempt to revolutionize policing to prevent revolution, Schrader explains. ${ }^{27}$

\footnotetext{
${ }^{20}$ Neocleous, Mark. The Fabrication of Social Order a Critical Theory of Police Power (Pluto Press, 2000).

21 Schrader, op. cit., p. 12.

22 Schrader, op. cit., p. 214.

23 Schrader, op. cit., p. 11.

24 Schrader, op. cit., p. 9.

25 Ibid.

26 Schrader, op. cit., p. 12.

27 Schrader, op. cit., p. 10.
}

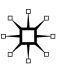




\section{Professionalization, pacification, counterinsurgency}

From 1954 to 1974, most US foreign police assistance was organized through the Office of Public Safety (OPS). "A small outfit with a large impact," ${ }^{28}$ Schrader notes, OPS contributed to unify police training and professional standards, and in just a few years established "a single repertoire" 29 in the US and abroad. Besides technical assistance, aid, and the training of foreign personnel, professionalization sought to improve the police's image by including the recruitment of members of minority groups and the reduction in open abuses and racism. A positive image of US policing seemed essential to counter critical voices, perceived as functional to Cold War enemies.

This was part of the response to what the architects of the system perceived as "an unruly globe," ${ }^{30}$ the book shows. In their view, it called for "a single bordercrossing war on crime and left-wing radicalism that utilized the same practical techniques and technologies and similar policies overseas and at home." Thus, the early concern with assisting economic development, institution building, and democratization, with initiatives led by the Agency for International Development was soon taken over by a focus on counterinsurgency and pacification, which became embedded in "police assistance to Third World countries." 31 Along these lines, the OPS, initially part of the US aid agency, over the years grew closer to the CIA.

The recurring, indistinct treatment of criminal suspects and political dissidents in documents and speeches seems remarkable, with all of them treated as threats capable of destabilizing order. After the initiative of often obscure pioneers, such as Byron Engle, who "recommended the use at home of lessons learned overseas,"32 the war on crime fused with the war on communism at home and abroad. With police training missions that expanded in 52 countries and with broader informal presence, OPS' ultimate goal was to "prevent communist revolution and crime," 33 Schrader notes. Dissent was growing.

At the time, US activists and critical intellectuals-including those close to the Black Panthers-were clear that, despite the rise of the civil rights movement, their treatment by the police was not substantially different than that of colonial populations. Often comparing themselves with the Vietnamese, ${ }^{34}$ critics described "links between war overseas and repression at home." 35 And as riots spread across the nation, from Detroit to Harlem, protesters made reference to "internal colonialism," denounced interlinked military and police apparatuses, and expressed solidarity with

\footnotetext{
${ }^{28}$ Schrader, op. cit., p. 6.

29 Ibid.

30 Ibid.

31 Schrader, op. cit., p. 9.

32 Schrader, op. cit., p. 5.

33 Schrader, op. cit., p. 6.

34 Schrader, op. cit., p. 3.

35 Ibid.
} 
third world countries. ${ }^{36}$ Yet agents in the US imperial police apparatus saw "national liberation" struggles or as struggles for civil rights as subversives in disguise. ${ }^{37}$

Just as the 1960s saw a rising number of protests, the Johnson administration launched a "war on crime" that included police reforms, new offices, large budgets, and growing imprisonment. Behind the official concerns with crime, radical activism was the main target, Schrader shows. In response, riot control and intelligence to identify potential communist agents entered the police's established repertoire, one in which preserving order, fighting crime, and eradicating subversion fused seamlessly "both at home and overseas." 38

Before the end of the decade, under the banner of police reform, similar training programs were exported to dozens of countries, especially to those undergoing decolonization. Mounted a language of police professionalization, training and assistance programs emphasized intelligence gathering, interrogation techniques, urban zoning, and riot control. That these terms involved training in torture and in forced disappearances became evident in the case of OPS adviser and torture advocate Dan Mitrione, represented by Ives Montand in Costa-Gavras' 1972 film State of Siege. Brought to Brazil, then to Uruguay, Mitrione was part of a decade long of OPS and CIA training of Uruguayan police both in Montevideo and Washington, revealed by techniques and technical devices used in torments "were of North American origin," 39 as recognized by a military official in the US. These practices were the unsaid of discourses of modernization and development.

Counterinsurgency was central to the endeavor. It sought to gain the population's "hearts and minds" to make them immune to radicalization, Schrader explains. Led by the police, it was seen as a "less-lethal, preemptive, and anticipatory approach to challenges to the state's legitimacy" 40 than open military action. At the same time, the term stands as "a misnomer," Schrader notes, as the insurgency alluded in the term "had not yet occurred," 41 as the actions were preemptive. Fusing police, military, and paramilitary training, counterinsurgency sought to complement the improvement in the economic conditions of compromised populations.

And so did pacification, with its origins on theaters of colonial war. From the battlefield in Vietnam to US cities, pacification targeted "entire populations" 42 blending an ambiguous amalgam of information and violence, benign and brutal practices. Thus, from the police's befriending of citizens-even schoolchildren-to scouting local leaders to promoting participation and community self-empowerment to

\footnotetext{
36 Ibid.

37 Schrader, op. cit., p. 11.

38 Schrader, op. cit., p. 9.

39 (Lieutenant Cooper, qtd. in) Heinz, Wolfgang. "Determinants of Gross Human Rights Violations by State and State-sponsored Actors in Argentina 1976-1983," Determinants of gross human rights violations by state and state-sponsored actors in Brazil, Uruguay, Chile, and Argentina, 1960-1990 (Heinz, Wolfgang S., and Hugo Frühling; Martinus Nijhoff Publishers, 1999).

40 Schrader, Badges without Borders, p. 13.

41 Schrader, op. cit., p. 14.

42 Schrader, op. cit., p. 3.
}

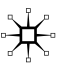


campaigns of terror, torture, forced disappearances (p. 155), and extrajudicial executions, pacification showed to have "no essence," 43 Schrader observes.

Activist and media revelations of the role of OPS training in abuses led to the closure of the office by the US Congress in $1975 .{ }^{44}$ Yet even among those critical of programs such as OPS, the notion may have prevailed that abuses had been carried out overseas, not in the US, and that police abuses in the US were unrelated to those linked to the role of OPS. Relying on representations of the police as law enforcement and of police abuses as deviant pathologies, such views get debunked by Schrader's work.

Names of offices and leaders as well as police techniques change while the imperial police crusade continues. In response to citizen demands for oversight that had led to the closure of OPS, police programs gained in decentralization, fragmentation, and secrecy, including the outsourcing of training programs as of irregular groups, from private security to death squads. ${ }^{45}$ Eventually, the Drug Enforcement Administration DEA, became the natural heir of OPS, absorbing its former agents and resources and joining in with the more recent US global wars on terror and on migrants.

\section{Renewing the good old police science}

For all its newness, technological innovation, and visionary sponsors, the US imperial police network drew on similar considerations of threats and nuisances than those of the old police science, if just "articulated to twentieth-century" 46 policing, as Schrader observes. With a main focus on promoting the state's strength, seventeenth and eighteenth century European police treatises distilled practical principles for maintaining order, as Michel Foucault's studies showed. With the ultimate goal to make the state stronger, police magistrates and rules had to shape behavior and control resources and the population at large. ${ }^{47}$ Police, different thinkers argued, had to promote morality and cooperation, prevent and manage epidemics and natural disasters, check on the food supply, trade, roads, rivers, and natural resources. To the same end, police agents would arrange mechanisms of surveillance to identify threats and nuisances and dispose of them-including their physical destruction. ${ }^{48}$ In the end, as a "governmental technology peculiar to the state," Foucault explains,

\footnotetext{
43 Schrader, op. cit., p. 10.

44 Schrader, op. cit., p. 11.

45 Huggins, Martha Knisely. Political Policing : the USA and Latin America (Duke University Press, 1998).

46 Schrader, op. cit., p. 14.

47 Foucault, Michel. "Governmentality," The Foucault Effect. Studies in Governmentality, ed. Graham Burchell, Colin Gordon, and Peter Miller (Chicago: The University of Chicago Press, 1991).

48 Dubber, Markus Dirk. The Police Power : Patriarchy and the Foundations of American Government (Columbia University Press, 2005).
} 
police defined distinctive practices instrumental to the preservation of the state. ${ }^{49}$ As a form of governmental reason, in its different iterations, raison d'état served as a matrix for the expansion of police in the seventeenth century, as it is the canvas of the US imperial police that Badges without Borders puts on display.

With the goal of "preservation, expansion, and felicity of the state," as Chemnitz puts it, allowing for "the most ready and swift means," the doctrine of raison d'état at once presupposes and seeks to secure the state's existence and expand its forces in an immanent, self-justifying move. ${ }^{50}$ Police defines one of raison d'état's main apparatuses ${ }^{51}$ instrumental to secure the state's self-perpetuation through methods including secrecy, crimes, and coup d'état. ${ }^{52}$ Police is key to prevent sedition, which Francis Bacon traced back to poverty and discontent. ${ }^{53}$ Thus, assisting the poor was as instrumental as chasing rebels and quelling revolts. Neither the main goals nor the strategies seem any different from those that the US imperial police has brought to the global scale. The copious evidence presented by Schrader shows how little of substance in terms of narratives, goals, and strategies has changed, other than the-of course, consequential-techniques, tools, and territorial reach. Thus, the twentieth century facets of the police science come into view in Schrader's book, as it maps the imperial police effort in gaining people's support as in neutralizing or destroying subjects deemed criminal, unruly, or radical. Constantly defining enemy identities and targeting them through policing and some "occasional" war, "the discretionary actions of police against revolution," Schrader observes, come to the forefront. $^{54}$

\section{Big mapping}

Reading Badges without Borders made me recall the experience of first learning about Operation Condor, the 1970s "Cold War-era assassination program," as Patrice McSherry described it, a clandestine terror network for chasing political dissidents across borders coordinated by the military dictatorships of Chile, Argentina, Uruguay, Paraguay, Bolivia, and Brazil. With US sponsorship and logistical support and its own designated death camps, Operation Condor was responsible for thousands of forced disappearances. ${ }^{55}$ Whereas, back in the $1970 \mathrm{~s}$, a number of forced disappearances suggested collaboration among governments, Condor was, of course, secret, and it remained for years confined to the corner of conspiracy theories. It was

\footnotetext{
49 Foucault, Michel. "Omnes et Singulatim: Towards a Criticism of Political Reason." The Tanner Lectures on Human Values (ed. S. McMurrin), Vol. II, 225-254. Univ. of Utah Press, 1981.

50 Foucault, Michel. Security, Territory, Population (Palgrave Macmillan, 2007), p. 330.

51 Foucault, Security, Territory, Population, p. 358.

52 Foucault, op. cit., p. 296.

53 Foucault, op. cit., p. 350.

54 Schrader, Badges without Borders, p. 41.

55 Scholarship ensued, as with Patrice McSherry's seminal work lifting the layers of collaboration and complicities between the US police and military authorities and their supporting politicians with the dictatorial Chile, Argentina,
} 
only when Martín Almada, a Paraguayan lawyer victim of torture detained for years under the Stroessner dictatorship, found a room full of documents in a police station outside Asuncion that the terror network came into view. "I6 "I'd heard about Operation Condor when I was in the belly of the condor itself," Almada reports in an interview, yet his was dismissed until he uncovered the archive of Condor, starting with the Chilean secret police's invitation to their Paraguayan peers to the group's 1975 founding meeting. ${ }^{57}$

Schrader's Badges without Borders follows on this path. Ambitious, exhaustive, drawing on an impressive collection of documents, "the archive of the police power," 58 as Schrader puts it, the work sets a landmark in reconstructing the US imperial security apparatus. The book brings into focus networks and practices that those familiar with police and security apparatuses know from specific case studies. Moving from its edges to the center, Schrader maps the global network of the US imperial police, exposing the canvas of which previously known incursions were part.

Just as an example, a significant literature has addressed the use of the figure of the "subversive," the internal enemy in Argentina. The label, as it is known, facilitated the dehumanizing of dissenters and brutal, and state terror policies-including tens of thousands of forced disappearances - under the framework of national security. Yet as Schrader shows, terms such as subversion were pivotal in Engle's discourse decades earlier. This is just one way in which Badges without Borders invites revisiting previous case and regional studies as pieces of a global, interconnected security puzzle.

In so doing, Schrader's research dispels at least two arguments that even critical US scholars hold to date. First, that US support for state terror policies overseas was rather episodical and the responsibility of a few unruly individuals - the "bad apples" argument. Second, that even those who committed abuses abroad may have done so at home, the land of the rule of law, as in any case police abuses in the US and abroad are unrelated. Such beliefs, Badges without Borders shows, are myths.

\section{Imperial police in the times of Covid-19}

Seeking to prevent and respond to crime treated alongside dissent, coordinated through open or cover policies, the counterrevolutionary, anti-democratic, ultimately antipolitical crusade has gone on for decades. Behind the appearance of modernization, technical sophistication, and legality, the US imperial project relied on the same police methods that the fictional Colonel Mathieu in Gillo Pontecorvo's film The Battle of Algiers condenses as "interrogation"- a code for torture and the implicit disposal of tortured bodies. The surgical violence of Cold

\footnotetext{
56 Watts, Simon, "How Paraguay's 'Archive of Terror' put Operation Condor in focus," $B B C$ News. www.bbc.com/news/magazine-20774985.

57 www.bbc.com/news/magazine-20774985.

58 Schrader, Badges without Borders, p. 15.
} 
War policing took a toll that in 1991 Charles Tilly conservatively estimated in 22 million lives.

As an ever changing transnational security apparatus perpetuates a muffled, allencompassing police war, the digital revolution-and the fourth revolution blur "the lines between the physical, digital, and biological sphere" ${ }^{59}$ and give birth to hybrid forms of corporate-police surveillance of unprecedented reach. This increasingly insidious capillary of surveillance, intelligence, and interventions presides over a social fabric that in the case of the US extends transnationally.

As I write these lines, the USA lies at the center of the Covid-19 pandemic, whose speed and scope attest to the global capitalist order imposed through the networks that Badges without Borders describes. ${ }^{60}$ While new cases expand, by the hour, governments take measures ranging from guaranteeing people's income to nationalizing hospitals and securing food delivery to the poor. Governments also use cell phone geolocation to track contagion as well as quarantine observation. ${ }^{61}$ Increasingly, security services monitor social media searching for signs of "social unrest." Denied in some cases, claimed to be anonymized tracking data when recognized, surveillance has been accompanied with zealous controls of quarantines and lockdowns across countries. Hundreds of thousands of detentions and thousands of arrests have been the response to people moving around without a permit, regardless of their need to get food or medicines, to assist relatives, or to work for those not lucky enough to be able to stay home. ${ }^{62}$ Killings have already taken place in response to protests, disobedience, and strikes. This, just as-mounted on the crisis-governments declare and extend emergency measures, and the US Attorney General demands calls for expanded powers of indefinite detention. While we may not know where this is heading, Schrader's book describes these very same practices and techniques as part of the assemblage of an US global imperial police apparatus. The life-preserving and life-destroying repertoire of police governance is now in full display.

The police chasing of radical ideas and radicals has limits, Schrader suggests. The success of the social order of capital may bring its nemesis, so artificial it is,

\footnotetext{
59 "The Fourth Industrial Revolution: what it means, how to respond," World Economic Forum, www. weforum.org/agenda/2016/01/the-fourth-industrial-revolution-what-it-means-and-how-to-respond/.

60 Surveilling and policing individuals and communities in search of terrorists did not prevent the dizzying spread of a virus by travelers, who only considering flights, amounted to over 4 and a half billion in 2019 alone. Statista, "Number of scheduled passengers boarded by the global airline industry from 2004 to 2020 (in millions)", www.statista.com/statistics/564717/airline-industry-passenger-traffic-globally/.

61 Lyons, Kim, "US government officials using mobile ad location data to study coronavirus spread," The Verge, Mar 29, 2020.

62 CORREPI, "Octavo reporte de aplicación del DNU 297/2020," March 29, 2020. www.corre pi.org/2020/octavo-reporte-de-aplicacion-del-dnu-297-2020/?fbclid=IwAR0kkTOZRYhLFnm0bBcTc9M8aQjquzGIJA9jttdZ_RxIHGAsO3FQBpmfdY; Cuarentena en números: 40 mil denuncias, 21 mil detenidos, 560 mil autos secuestrados

Cuarentena en números: 40 mil denuncias, 21 mil detenidos, 560 mil autos secuestrados, Perfil, April 1, 2020

www.perfil.com/noticias/policia/coronavirus-casi-800-mil-personas-violaron-cuarentena-argentina. phtml?fbclid=IwAR0TQ-zbRI8VuOqurh5AC4tGswgk6Gj9_CLwTXZWSe4K7vnYh51VzaW9xe0.
} 
so ultimately alien to life. If fully deployed, it risks asphyxiating the social order that it seeks to protect and reproduce. We will see now how this conflict unfolds. In the meantime, Badges without Borders provides us with the much needed canvas.

Publisher's Note Springer Nature remains neutral with regard to jurisdictional claims in published maps and institutional affiliations. 